\title{
社会資本の維持管理技術確立のための腐食環境評価
}

\author{
押川渡 ${ }^{\mathrm{a}}$ \\ ${ }^{a}$ 琉球大学 工学部 ( $=903-0213$ 沖縄県中頭郡西原町千原 1)
}

\section{Corrosion Environment Evaluation for Maintenance Management of Infrastructure}

\section{Wataru OSHIKAWA ${ }^{\text {a }}$}

${ }^{\text {a }}$ Faculty of Engineering, University of the Ryukyus(1, Senbaru, Nishihara-cho, Nakagami-gun, Okinawa 903-0213)

Keywords : ACM Sensor, Relative Humidity, Sea Salt, Corrosion Rate

\section{1.はじめに}

鋼構造物は, 橋梁, 港湾, 建築物などの社会資本が主体を なしている。高度経済成長期に建設されたこれらの社会資本 も2020 年代には 50 代を迎え, 劣化損傷が多発する危険性が 高まってきており，老朽化改修や更新の時期を迎えつつある ${ }^{1)}$ 。 現在の我が国の財政状況を考慮すると, 新設ではなく, 補修. 補強による延命化によって対処することになりそうである。 そのためには，個々の社会資本の劣化状況の把握とその寿命 予測および，劣化状況に対応した補修・補強が必要である。 鋼構造物の主な劣化要因として, 腐食と疲労が挙げられるが, 腐食は大きなウェイトを占めている。本稿では, 社会資本の 維持管理に関して腐食環境評価の観点から概説する。

\section{2. 大気腐食の水膜厚さによる分類}

鋼構造物の大気腐食は, 水と酸素 (溶存酸素)の供給により 進行する。水溶液中での腐食では水は十分に存在しているの に対し, 溶存酸素の供給が制限される。大気中での腐食はそ の逆で, 酸素は十分あるが水の供給が限られる。大気中で水

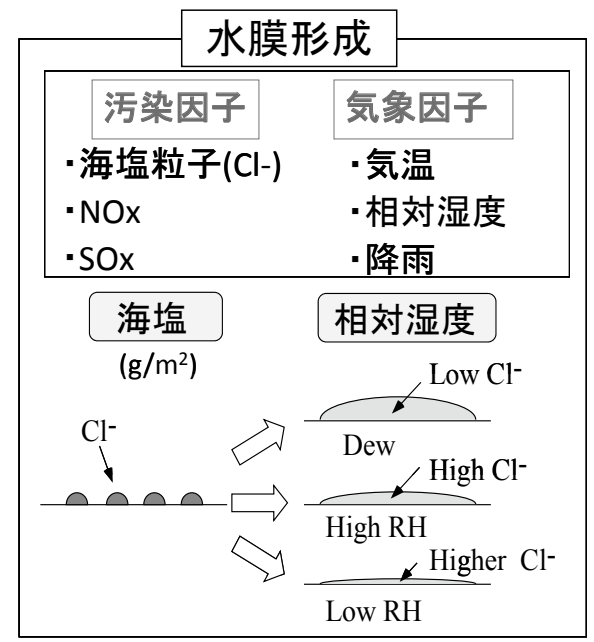

図 1 水膜形成
分を与えるのは, 降雨, 結露, および大気中の湿分による目 に見えない薄い水膜であり，これに大気の成分 $\left(\mathrm{O}_{2}, \mathrm{CO}_{2}\right)$ お よび污染物質 $\left(\mathrm{SO}_{2}, \mathrm{NH}_{3}\right.$, 海塩など $)$ が溶解して電解質溶液 を形成する(図 1)。金属表面では気象条件に応じて“乾燥” と“濡れ”が繰り返されるので, 水膜としての電解質溶液の 量および濃度が気象条件に対応して激しく常に変化するのが 特徴であり, それに対応して, 腐食の進行と停止が繰返され ることになる。

Tomashov ${ }^{2)}$ は図 2 に示すように, 大気腐食を金属表面に存 在する水膜厚さにより, 乾き大気腐食 (Dry Atmospheric Corrosion), 湿り大気腐食(Moist Atmospheric Corrosion), 濡 れ大気腐食 (Wet Atmospheric Corrosion)に分類した。すなわち, 乾き大気腐食 (水膜厚さ：10 nm 以下)では, 水膜が薄く電解 質として働かず腐食は起きない。湿り大気腐食の領域 (水膜 厚さ： $10 \mathrm{~nm} \sim 1 \mu \mathrm{m}$ ) では, 水膜が厚くなるにつれ，これが 電解質として作用するようになり, 電気化学的な腐食が進行 し腐食速度が増加する。しかし, 濡れ大気腐食(水膜厚さ：

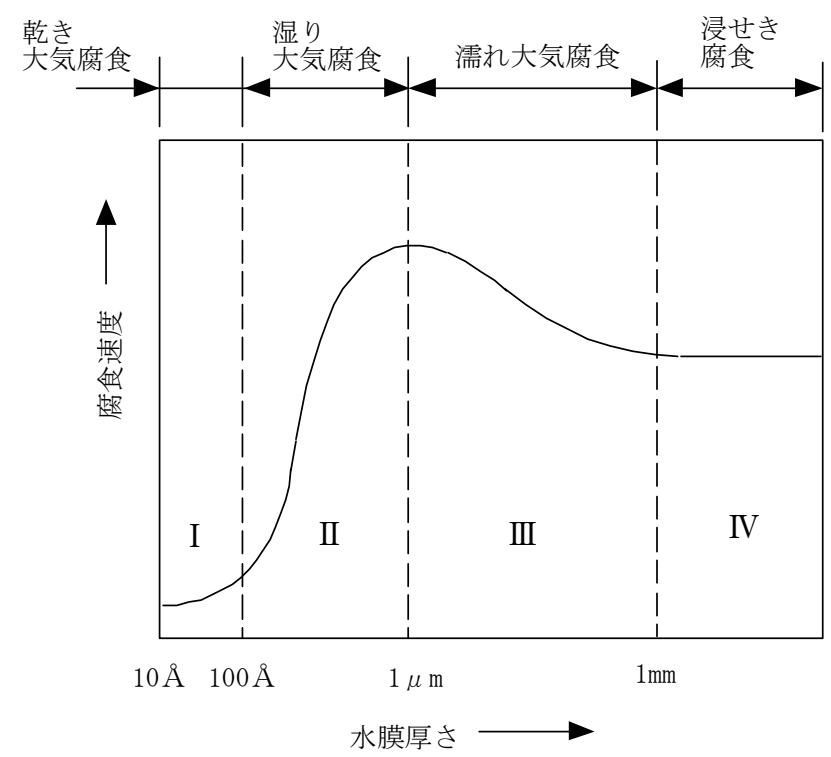

図 2 Tomashovによる水膜厚さと腐食速度の関係 
$1 \mu \mathrm{m} \sim 1 \mathrm{~mm})$ の領域になると, 水膜を介しての酸素の拡散が 必要になるため, 水膜厚さの増加につれ腐食速度が小さくな る。そして, 酸素の拡散層の厚さに相当する水膜厚さ $(1 \mathrm{~mm})$ 以上になると, 腐食速度は一定となり水膜厚さに依存しなく なるというものである。Tomashov は, 湿り大気腐食と濡れ 大気腐食の境界である水膜厚さが約 $1 \mu \mathrm{m}$ で腐食速度が極大 になると報告した。これに対し，インピーダンス法や Kelvin 法を利用した測定結果から, 数 $10 \mu \mathrm{m}$ から約 $100 \mu \mathrm{m}$ で最大

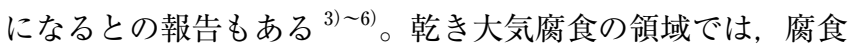
はあまり進行しないことから，実質的に，大気腐食は湿り大 気腐食と濡れ大気腐食の領域で起こる現象であると推察され る。

\section{3. 海塩が吸湿して形成する水膜厚さの推定}

実際の大気環境において金属表面への水の供給は，降雨と 結露が主体となる。それ以外には表面に吸湿性の物質, 例え ば, 海塩が付着している場合であり, 相対湿度がある限度を 超えると吸湿が生じる。海塩はそのほとんどが風に乗って内 陸へ運ばれるが，風向，風速，海岸線からの距離，障害物の 有無などによって，飛来する量が決定される。海塩以外に問 題となるのが, 冬季に路面に散布する凍結防止剤がある。凍 結防止剤には, $\mathrm{NaCl}, \mathrm{CaCl}_{2}$ および $\mathrm{MgCl}_{2}$ などの塩化物系が 多用される。しかし，散布後に鋼材の腐食に及ぼす影響が厳 しいため，酢酸系も利用されている7)。

飛来海塩量の測定にはJIS Z 2382 に規定されているドライ ガーゼ法, ウェットキャンドル法や土研式がある。いずれも ある一定期間に飛来する量を測定しており，必ずしも実際の 鋼板上に付着している海塩量 (塩分量) と一致しているとは言 い難い。飛来量も重要ではあるが, むしろ付着量が腐食量と 直接関係して㧍り重要だと考えている。

そこで, 海塩が付着した場合に吸湿してできる水膜の組成 と水膜厚さを，熱力学的に算出した例について簡単に紹介す る ${ }^{8)}$ 。海水の組成は $\mathrm{NaCl}$ が約 $78 \%, \mathrm{MgCl}_{2}$ が $9.6 \%$ 含まれ, それ以外に $\mathrm{MgSO}_{4}, \mathrm{CaSO}_{4}, \mathrm{KCl}$ などが少量含まれている。今, 密閉した容器内に飽和溶液を置くと, 容器内の相対湿度 $(\mathrm{RH})$ と溶液の活量(濃度)が平衡するように, 容器内の水分を吸湿 あるいは溶液の蒸発が生じ，相対湿度が一定に保たれる。例 えば， $\mathrm{NaCl}$ は約 $\mathrm{RH} 76 \% ， \mathrm{MgCl}_{2}$ は約 $\mathrm{RH} 33 \%$ で一定になり， それ以上の相対湿度になると, 周囲の水分を吸湿し始める。 飽和溶液だけでなく，濃度を種々の值に変化させた場合につ いて, 平衡する相対湿度を計算すると, 塩化物溶液の種類に 関係なく，塩化物イオン $\left(\mathrm{Cl}^{-}\right)$でほぼ整理することができた。 この関倸を単独塩から, $\mathrm{NaCl}$ と $\mathrm{MgCl}_{2}$ の混合塩 $\left(\mathrm{Mg}^{2+} / \mathrm{Na}^{+}\right.$ $=0.11$ ) と仮定した海塩の場合へと拡張した場合についても 検討し, 計算の妥当性が確認された。詳細は文献 ${ }^{8)}$ を参照し て頂くとして，その結果を図 3 に示す。塩化物イオン濃度が わかれば，平衡する相対湿度を求めることができる。逆に， 相対湿度を決めれば, 塩化物イオン濃度, すなわち, 付着し た塩が吸湿してできる水膜の濃度が決まることを意味してい る。海塩が吸湿してできる水膜の密度は, 塩化物イオン濃度 により整理できるので，密度と組成の関倸を用いて，水膜厚 さが推定可能となる。水膜厚さは, 海塩付着量 $(\mathrm{Ws})$ が $0.01 \mathrm{~g} /$

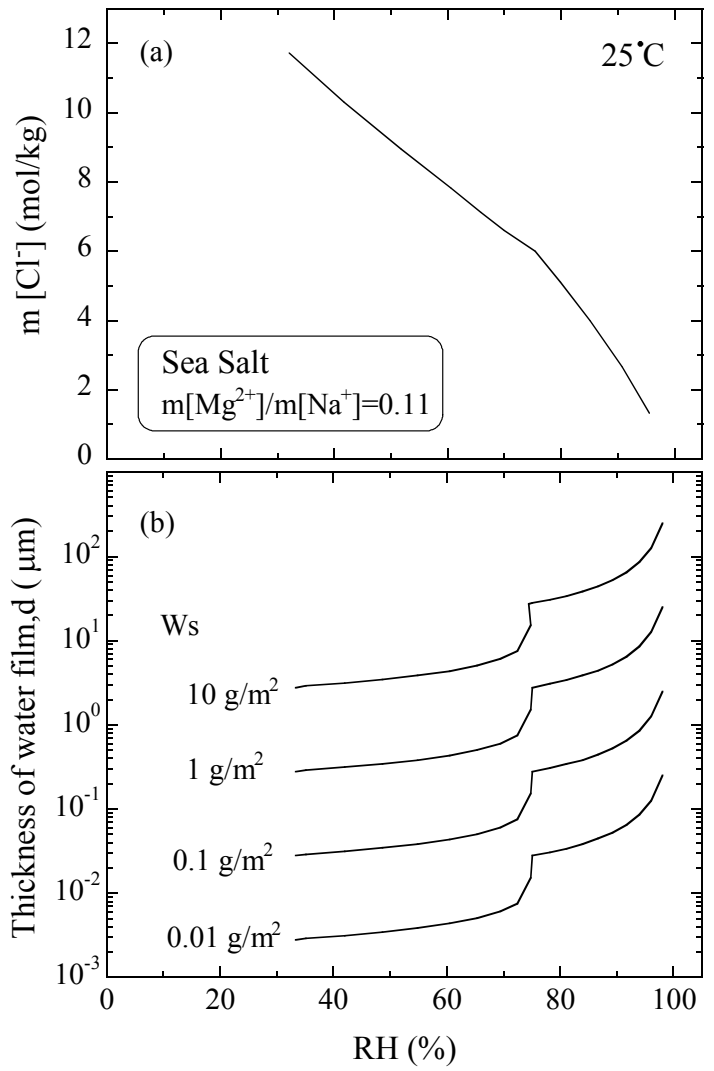

図 3 海塩が付着して形成する水膜濃度と水膜厚さの RH 依存性

$\mathrm{m}^{2}$ 以上であれば，Ws に比例して増加する。 $\mathrm{MgCl}_{2}$ が潮解す るRH33\%から相対湿度の上昇とともに徐々に水膜厚さは厚 くなり， $\mathrm{NaCl}$ が潮解する $\mathrm{RH} 75 \%$ を超えると，急激に水膜 厚さが増加することとなる。例えば Ws $=1 \mathrm{~g} / \mathrm{m}^{2}$ の場合, $\mathrm{NaCl}$ が溶解する $\mathrm{RH} 75 \%$ 以上では $3 \sim 30 \mu \mathrm{m}$ であるのに対し， RH75 \% 以下では $0.3 \sim 0.7 \mu \mathrm{m}$ に留まる。

要するに，金属表面には周囲の相対湿度に応じて，目に見 えないほどの水膜が存在し, 相対湿度が高いと水膜厚さは厚 くなる。さらに海塩が付着することで, 相対湿度に応じて吸 湿量が増加する。相対湿度が同じであれば，吸湿してできる 水膜の濃度は一定であるので, 海塩量が多いほど, 水膜厚さ は増加することとなる。

\section{4. 環境評価手法}

鋼橋の防食技術の一つとして耐候性鋼材を用いる方法があ る。耐候性鋼材は, 表面に緻密なさび層(保護性さび)を生成 することで，腐食を次第に抑制する特性を有している。鋼橋 用として JIS G 3114 規格の耐候性鋼 (SMA)の無塗装用が一 般に広く使用されている。しかし, 厳しい腐食環境によって は保護性を十分発揮しない場合もあり，その適用範囲は，海 からの飛来塩分量が少ない地域 (0.05 mdd 以下) に限定され ている9)。あるいは，離岸距離を提示し，それ以上であれば 飛来塩分量測定を実施せずに適用可としている。飛来塩分量 の測定期間は，1力月間とされており，測定場所や方位，季 節変動が無視できないことから 1 年間 (12 回) 測定を行うこ とを考虑すると, かなりの手間がかかる。一方，新たな現地 環境評価手法として耐候性鋼材の腐食減耗量の予測に基づく 
検討がなされてきている ${ }^{10) \sim 13) 。 ~}$

耐候性鋼材の腐食減耗予測式は次式で示されている。

$\mathrm{Y}=\mathrm{A} \cdot \mathrm{X}^{\mathrm{B}}$

ここで, $\mathrm{A}$ 值は $\mathrm{X}=1$ (年) とした時の腐食減耗量 $\mathrm{Y}$ 值に 相当し, 局部環境腐食性指標と呼ばれる。 $\mathrm{B}$ 值はさびの保護 性の上昇に伴う腐食速度低減の度合いの逆数に相当すること から，1/B 值を保護性さび形成効果指数と呼んでいる。全国 41 橋の桁下暴露試験デー夕 ${ }^{14,15)}$ より, A 值と B 值の関係が 定式化され， $\mathrm{A}$ 值がわかれば， $\mathrm{B}$ 值の推定が可能となった。 1 年間の腐食減耗量を測定すれば， $\mathrm{A}$ 值から $\mathrm{B}$ 值が推定でき， 経年腐食減耗量が予測できるわけである。したがって，より 精度の高い A 值を求めることが要求される。実際上は, ワッ ペン試験片と称する，40〜 $70 \mathrm{~mm}$ の耐候性鋼試験片を原則 1 年以上，実橋梁に直接貼り付ける，あるいは仮設の簡易暴 露架台の専用装着板に接着するワッペン式暴露試験で求めら れている。

\section{ACM (Atmospheric Corrosion Monitor) 型腐食 センサ}

大気環境における鋼構造物の多くは，部材や部位によって 腐食環境が異なる場合が少なくない。例えば，鋼 I 桁橋では， 外桁や内桁，さらにはスパン中央部や桁端部などの構造部位 により腐食環境が異なる。したがって, 鋼構造物を適切に維 持管理するためには，構造物の架設地点における温湿度，飛 来塩分量や風向・風速などのマクロ腐食環境のみではなく, 構造部材・部位レベルのミクロ腐食環境を精度良く評価する ことが重要であると言える。

その方法の一つが前述のワッペン式暴露であるが，腐食状 況をモニタリングすることが可能な ACM 型腐食センサ ${ }^{16,17)}$ (以下，ACM センサ）を併用することが多い。

$\mathrm{ACM}$ センサの概観を図 4 に示す。基板 Fe（あるいは $\mathrm{Zn}$ )

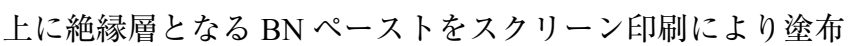
後, 焼成硬化させる。その後, 導電性 $\mathrm{Ag}$ ペーストを基板と の絶縁が保たれるように絶縁層の上に積層印刷し，焼成硬化 させる。2 種類の金属が互いに絶縁状態にあるが，ACM セ ンサ上に雨水や結露などの薄い水膜が形成されると，基板 $\mathrm{Fe}$ (あるいは $\mathrm{Zn}$ )をアノード, Ag をカソードとしたガルバ ニック電流が生じることとなる。
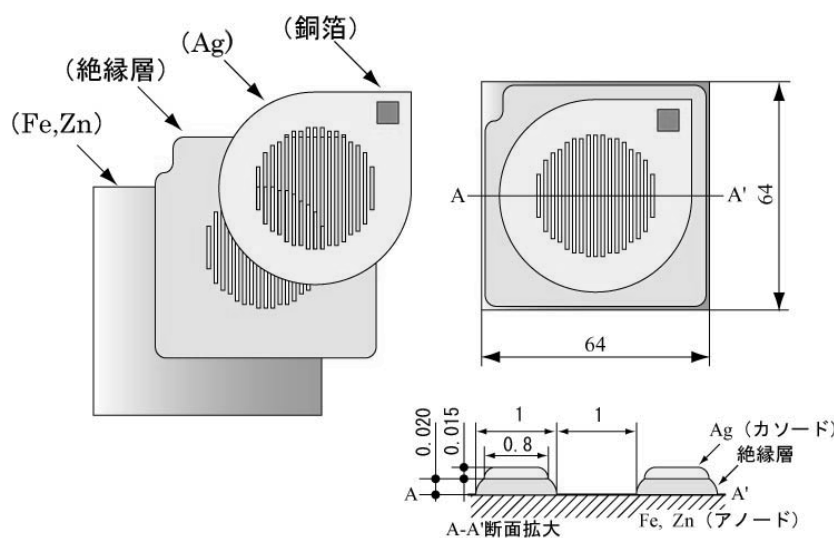

図 4 ACM センサの概略
$\mathrm{ACM}$ センサを大気環境に曝しておくと，一般的には，夜 間の結露に伴い ACM センサ出力が増大し, 日中は気温の上 昇および相対湿度の低下により ACM センサ出力も低下する 傾向を示す。降雨時には，結露時に比較して 1 ～ 2 桁大きな 出力となることから，降雨や結露を区別して判定することが 可能である。また, 得られた ACM センサ出力と腐食速度と の間の関係式も提案されている ${ }^{18) ~ 20) 。 ~}$

図 5 は大気環境でのモニタリングにより得られた ACM セ ンサ出力をその時の相対湿度 RH に対してプロットすること で，海塩付着量が推定できることを示した図である。あらか じめ一定量の海塩 $\left(\mathrm{Ws}=0.0001 \sim 10 \mathrm{~g} / \mathrm{m}^{2}\right)$ を付着させた ACM センサを，30\%RHに保持し，5\%ずつ上昇させ， $90 \% \mathrm{RH}$ まで上昇後，同様に $30 \% \mathrm{RH}$ まで下降させた。その際の $\mathrm{ACM}$ センサ出力を図 5 の破線で示す(校正曲線)。海塩が付 着していない場合, $\mathrm{ACM}$ センサ出力は $90 \% \mathrm{RH}$ でも検出さ れないが, 海塩が付着すると, その量に応じて ACM センサ 出力が増大する。図中のプロットは，5日目までは Ws= $0.01 \mathrm{~g} / \mathrm{m}^{2}$ 上に分布しているが，期間の経過とともに増加し， $\mathrm{Ws}=1 \mathrm{~g} / \mathrm{m}^{2}$ まで増加していることがわかる。すなわち, $\mathrm{ACM}$ センサ出力と相対湿度から, 海塩付着量を推定できる こととなる。

以下では，実橋梁における ACM センサによる腐食環境評 価を行った例を示す。

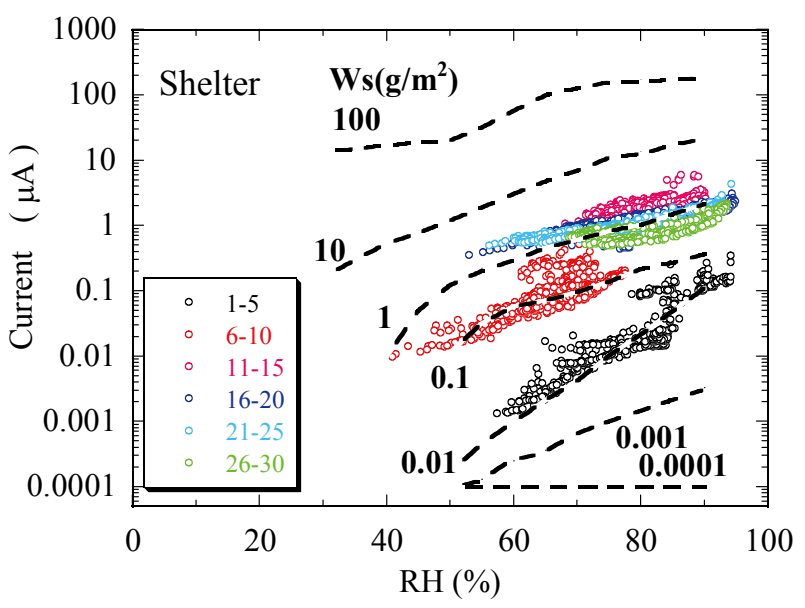

図 $5 \mathrm{ACM}$ センサ出力から推定した海塩付着量 $(\mathrm{Ws})$ の推移
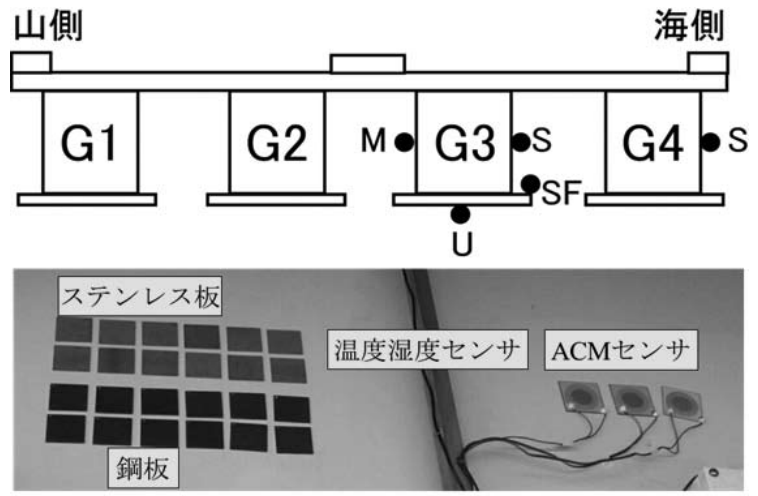

図 6 センサの設置箇所と設置状況 


\section{6. 実橋梁における ACM センサによる腐食環境評価}

海岸から約 $1 \mathrm{~km}$ の距離にある那覇市の実橋梁において, ACM センサを用いた部位別の環境モニタリングを行った。 図 6 に示すように, 雨に濡れない内桁 G3 桁および外桁 G4 桁を対象とした。G3 桁では, 山側 (G3M) と海側 (G3S)のウェ ブ面，および下フランジ下面(G3U) にセットした。下フラン ジ上面海側 (G3SF) は上向きにセットした。G4 桁では雨のか かる海側ウェブ面 $(\mathrm{G} 4 \mathrm{~S})$ を選定した。それぞれの部位に $\mathrm{ACM}$ センサ, 温湿度センサと鋼板試験片, 海塩付着試験片 を取り付けた。 ACM センサには Fe および Zn めっきを基板 とする 2 種類を用い, 毎月交換および最長 1 年の長期連続モ ニタリングした。温度・湿度はセンサ出力とともに 10 分間 隔で記録した。また, 鋼板試験片は毎月および長期暴露し, 回収後の重量減から腐食速度を求めた。毎月および長期の海 塩付着量を計測するために, ステンレス鋼板を暴露し, 回収 後, イオン分析計にて塩化物イオン量を測定し海塩付着量を 算出した。

\section{1 海塩付着量と腐食減耗量}

毎月の部位別の海塩付着量は, 雨に濡れない内桁の G3S, G3M, G3U は非常に小さく, 約 $20 \mathrm{mg} / \mathrm{m}^{2}$ 程度であった。 G3SF は G3 椼下フランジ上面に設置している影響もあり， 毎月 $100 \mathrm{mg} / \mathrm{m}^{2}$ を超えていた。それに対し, 雨のかかる外桁 の $\mathrm{G} 4 \mathrm{~S}$ では 9 月の台風時には $100 \mathrm{mg} / \mathrm{m}^{2}$ を超えたが, それ
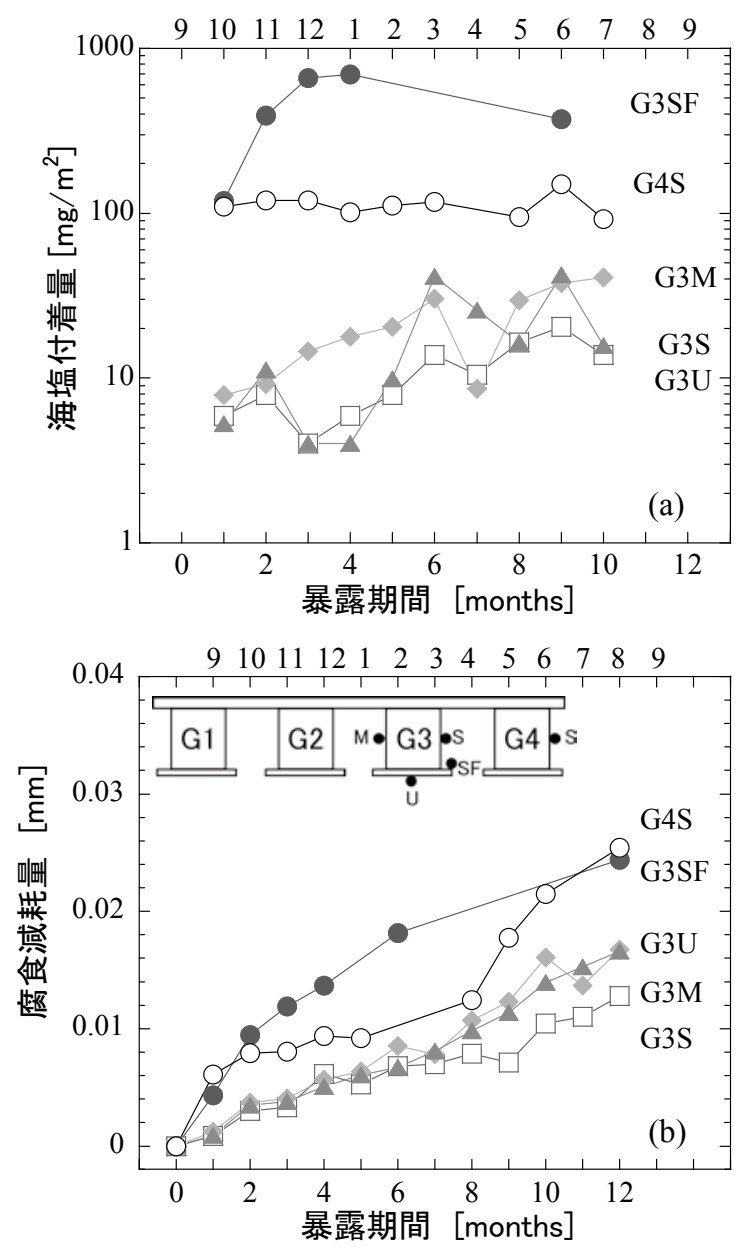

図 7 実橋梁における海塩付着量 (a) と腐食減耗量 (b)の推移
以外の月では $40 \mathrm{mg} / \mathrm{m}^{2}$ 以下と多くなかった。降雨の洗浄作 用を受けるためである。長期の付着量は, 図 7 (a)に示すよ うに内桁 (G3U, G3M, G3S) では暴露期間とともに増加する 傾向にあり, 海側, 山側の影響は小さい。これは設置環境が 周囲をビルに囲まれているためと考えられる。下フランジ上 面 G3SF では，最も多く付着しており，約 $500 \sim 800 \mathrm{mg} / \mathrm{m}^{2}$ と高い值を維持している。外桁の G4S は, ほとんど変化が なく, $100 \mathrm{mg} / \mathrm{m}^{2}$ でほぼ一定であり, この值は中田らの報告 ともほぼ一致している ${ }^{21)}$ 。鋼板の腐食減耗量は, 月ごとに 異なっており, 台風の通過した月は G4S の腐食量が大きいが, それ以外の月では, 下フランジ上面の G3SF が大きかった。 内桁であるのでほとんど雨に濡れないことを考慮すると, 海 塩付着量の影響が大きいといえよう。温度と湿度を各部位で 計測したが, 外桁と内桁での違いはあるものの, 内桁の位置 による違いはほとんどなかった。外桁の G4S の腐食量が内 桁とさほど変わらないのは, 海塩付着量は多いものの, 風の 影響を受けて乾燥しやすいことや, 日中の気温の上昇および それに伴う湿度の低下などが関与しているものと考えられる。

図 7 (b) に腐食減耗量の推移を示すが, 短期の腐食減耗量 の順列とほほ同様であった。下フランジ上面の G3SF が初期 から大きく, 外桁の $\mathrm{G} 4 \mathrm{~S}$ は 11 月から 3 月の冬場には増加傾 向が小さいが, それ以降, 急激に増加して, $0.025 \mathrm{~mm}$ となっ た。試験片には炭素鋼を用いたので, 耐候性鋼であれば，さ らに腐食減耗量は小さくなることが予想される。以上のよう に, 海塩付着量が大きい部位で腐食減耗量も大きくなること がわかる。

\section{6. $2 \mathrm{ACM}$ センサ出力}

基板が $\mathrm{Fe}$ の $\mathrm{ACM}$ センサは, 耐久性が低下するため, 毎 月新品と交換が必要とされているが, 内桁では濡れにくいこ とから長期間の連続モニタリングも行った。その結果を図 8 に示す。海塩付着量および腐食減耗量が小さかった内桁 (a) では，ほぼ同じ出力傾向にあり，0.1 $\mu \mathrm{A}$ を超えることがわ ずかしかない。得られた ACM センサ出力から計算された腐 食速度は $0.016 \mathrm{~mm} / \mathrm{y}$ であり，実測值とほとんど一致した。 また, 海塩付着量および腐食減耗量の大きかった下フランジ 上面 G3SF (b) のセンサ出力はかなり変動が大きいことがわ かる。同様に降雨の影響をうける G4S (c)の ACM センサ出 力も大きい。 $\mathrm{G} 4 \mathrm{~S}$ は降雨の影響を受けて, センサ櫛部の劣化 が激しく, 期間の経過とともに不安定となった。ただし, 基 板が $\mathrm{Zn}$ の ACM センサ出力は 1 年の継続したモニタリング にも有効であった。G3SF の ACM センサ出力から得られた 腐食速度は $0.056 \mathrm{~mm} / \mathrm{y}$ であり, 実測值 $0.024 \mathrm{~mm} / \mathrm{y}$ よりも 2 倍程度大きな值を示した。ACM センサ出力から腐食速度を 推定することは可能ではあるが, 精度に関してはまだ検討の 余地がある。

1 年間の腐食減耗量はワッペン試験片で実測できるのであ るから, むしろ, その測定期間中の腐食環境の変化をモニ夕 リングする点に重点を置く方が望ましい。腐食減耗量の值だ けでは, 腐食減耗量が大きい(小さい)のは, 降雨, 海塩(塩分) のどちらの影響なのか不明になりやすい。腐食環境が突然, 変化していないかなど, 原因究明の点からも ACM センサに よるモニタリングは有効となるであろう。そのためには, 特 


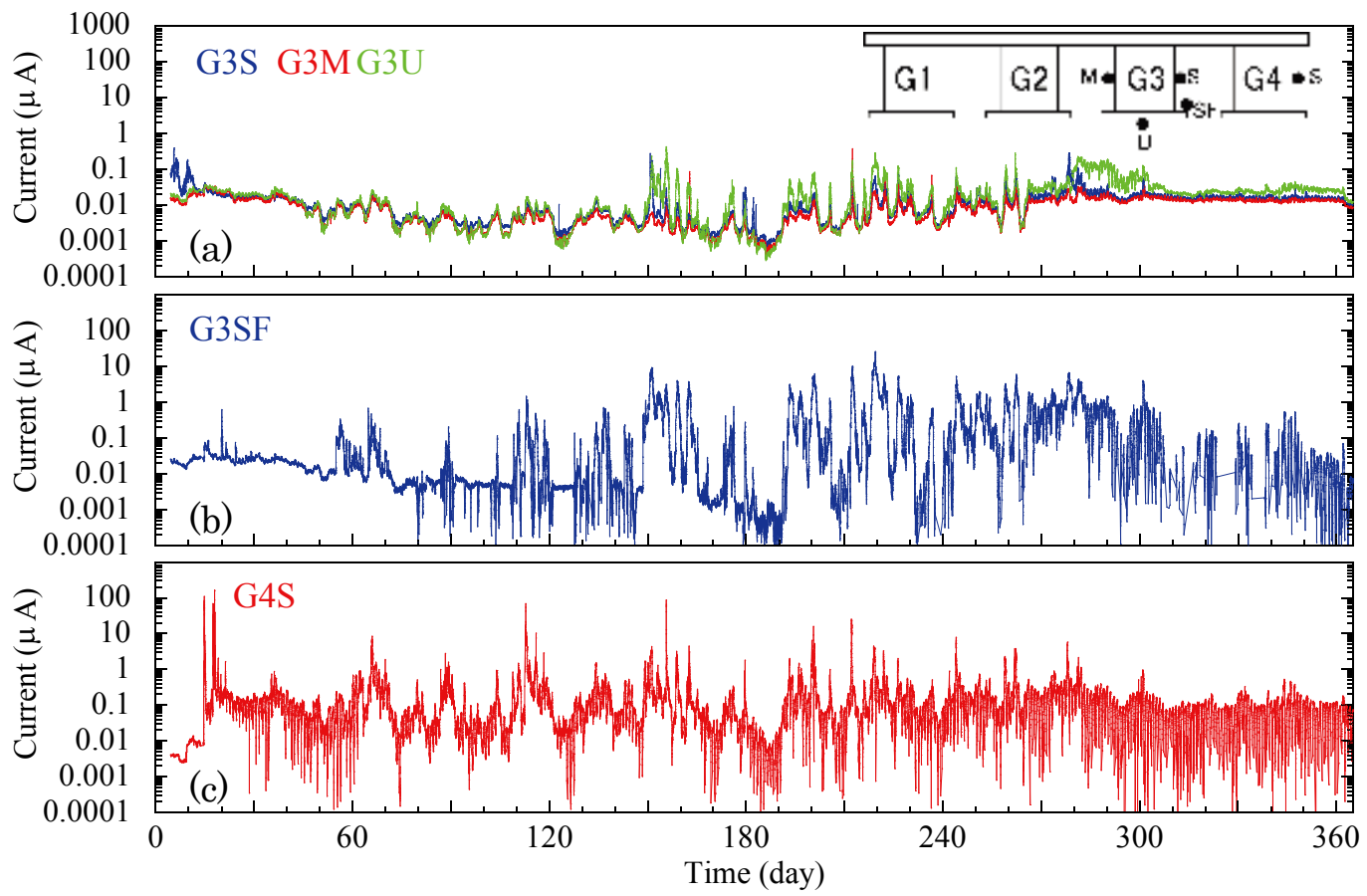

図 8 ACM センサ出力

に Zn 基板の ACM センサの DATA の蓄積および解析が望ま れる。

\section{3 海塩付着恒湿腐食試験}

図 9 に実験室において, 一定量の海塩を付着させた普通鋼 板を相対湿度を一定に保持した恒湿容器内に 1 年間保持した 場合の腐食減耗量を示す ${ }^{22)}$ 。超音波霧化装置を用いて海塩 を均一散布し乾燥させ, 重量変化により海塩量が既定の值に なった試料のみを選別して実験に供した。密閉容器内の相対 湿度は飽和塩水溶液を用いることで $58 \% \mathrm{RH}, 75 \% \mathrm{RH}$,

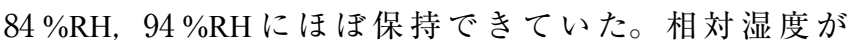
$60 \%$ RH 以下であれば，海塩付着量の影響はあまり受けず， 1 年間の腐食減耗量は $0.012 \sim 0.014 \mathrm{~mm}$ であった。相対湿 度が高く, 海塩付着量が多いほど, 腐食減耗量は増大し, 海 塩付着量 $1 \mathrm{~g} / \mathrm{m}^{2}$ で $94 \% \mathrm{RH}$ に保持した場合， $0.065 \mathrm{~mm}$ で最 大となった。3.で述べたように，海塩付着量が多く，相対 湿度が高いと水膜厚さは厚くなることから, 水膜厚さと関係 していると考えられる。海塩量と相対湿度との関係より計算 される水膜厚さは約 $10 \mu \mathrm{m}$ となる ${ }^{8)}$ 。

耐候性鋼橋梁の腐食減耗量が $0.5 \mathrm{~mm} / 100$ 年以下を目標と する耐腐食性能レベル I においては，局部腐食環境性指標 A のしきい值が $0.030 \mathrm{~mm}$ と提案されている ${ }^{11)}$ 。本実験では鋼 材が普通鋼であること, 実環境では温度および湿度の変動が あること, 水平上向きでの試験のため, 腐食生成物の堆積が あることなどを考慮すると，直接，比較することはできない。 しかし, 今後の橋梁の維持管理において海塩付着量の管理レ ベルをいくらにするのかなど，参考になると考えている。現 在，耐候性鋼で同実験を計画中であり，根拠のあるデータの 蓄積が必要と考えられる。

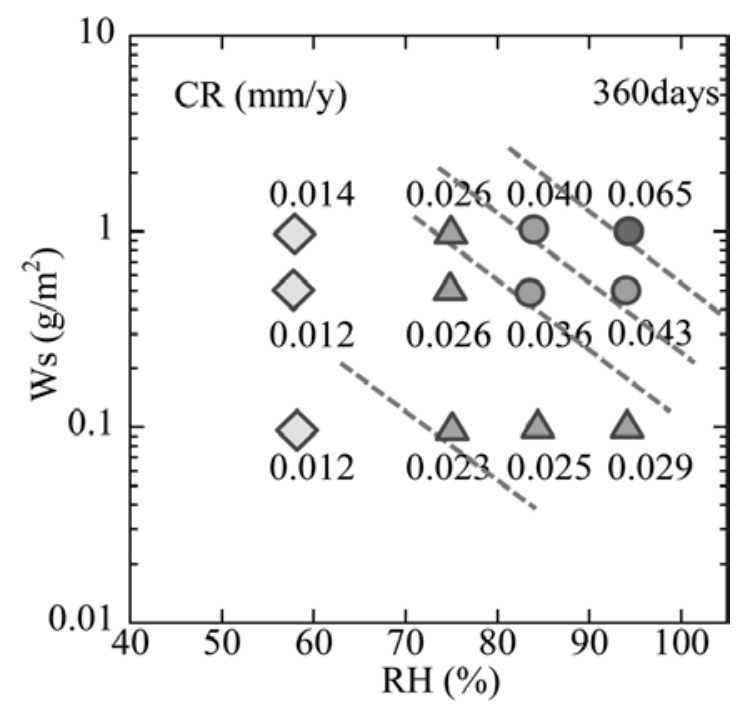

図 9 海塩付着恒湿腐食試験における腐食速度

\section{7. おわりに}

社会資本，主に鋼橋の維持管理技術としての腐食環境評価 について概説した。鋼橋の防食方法として最も多いのは，塗 装，耐候性鋼および溶融亜鉛めっきである。また, Zn-Al 溶 射や $\mathrm{Al}-\mathrm{Mg} 5 \%$ 溶射などの金属溶射も採用され，さらに塗装 を施す場合もある。いずれも海塩あるいは凍結防止剤の塩分 が付着すると劣化が促進される。塩分の管理として，それら の付着量の検出精度向上やガーゼ法に代わる簡単で精度の高 い塩分測定方法が求められる。それらが環境評価につながり, 維持管理に生かされるものと考えている。また劣化を予測す る技術，診断する技術，劣化した材料の補修技術の向上も今 後の課題となるであろう。

（Received December 28, 2012） 


\section{文献}

1 ) 坂野昌弘; 土木学会誌, 95, (12), 36 (2010).

2 ) N. D. Tomashov; Atmospheric Corrosion of Metals, p.367 (MacMillan, 1966).

3 ) 細矢雄司, 篠原 正, 押川 渡, 元田慎一; 材料と環境, 54, 391 (2005).

4) 西方 篤, 高橋岳彦, 候 保栄, 水流 徹; 材料と環境, 43,188 (1994).

5 ) 山本正弘, 片山英樹, 小玉俊明; 日本金属学会誌, 65, 465 (2001).

6 ）山下正人, 土井教史, 長野博夫 ; 材料と環境, 47, 384 (1998).

7 ）木村恵子, 曽根真理, 並河良治, 桑原正明, 角湯克典; 国土技術政 策総合研究所資料 No.412, 8 (2007).

8 ) 押川 渡, 篠原 正, 元田慎一; 材料と環境, 52, 293 (2003).

9 ) (社)日本道路協会; 道路橋示方書 - 同解説, I共通編, II鋼橋編 (平成 14年3月)

10）三木千壽, 市川篤司, 鵜飼 真, 竹村誠洋, 中山武典, 紀平 寛 ; 土 木学会論文集, No.738/I-64, 271 (2003).

11）(社)日本鋼構造協会; 而候性橋梁の可能性と新しい技術, テクニカ ルレポートNo.73 (2006).

12）紀平 寛, 田辺康児, 楠隆, 竹澤 博, 安波博道, 田中睦人, 松
岡和巳, 原田佳幸; 土木学会論文集, No.780/I-70, 71 (2005)

13）鹿毛 勇, 塩谷和彦, 竹村誠洋, 小森 務, 古田彰彦, 京野一章; 材 料と環境, 55, 152 (2006).

14）建設省土木研究所, 社鋼材俱楽部, (社)日本橋梁建設協会; 耐候性 鋼材の橋梁への適用に関する共同研究報告書 $(\mathrm{XV})$, 第71号 (平 成4年3月).

15）建設省土木研究所, (社)鋼材俱楽部, 社)日本橋梁建設協会; 而候性 鋼材の橋梁への適用に関する共同研究報告書 $(\mathrm{XX})$, 第88号 (平 成5年3月)。

16）元田慎一, 鈴木揚之助, 篠原 正, 兒島洋一, 辻川茂男, 押川 渡, 糸村昌祐, 福島敏郎, 出雲茂人 ; 材料と環境, 44, 218 (1995).

17）篠原 正, 元田慎一, 押川 渡; 材料と環境, 54, 375 (2005).

18）押川 渡, 糸村昌祐, 篠原 正, 过川茂男; 材料と環境, 51, 398 (2002)

19）押川 渡, 佐々木裕也, 篠原 正; 第52回材料と環境討論会, 53 (2005).

20）貝沼重信, 山本悠哉, 伊藤義浩, 押川 渡 ; 材料と環境, 60,497 (2011).

21） 中田潮雄, 森田 大, 辻川茂男; 第47回材料と環境討論会, 17 (2000)

22）押川 渡, 山田 学, 中野 敦; 材料と環境, 59, 390 (2010). 